2018

\title{
Attitudes about gifted education among Irish educators
}

Tracy L. Cross

College of William and Mary, tlcross@wm.edu

Jennifer Riedl Cross

College of William and Mary, jrcross@wm.edu

Colm O'Reilly

Dublin City University

Follow this and additional works at: https://scholarworks.wm.edu/educationpubs

Part of the Gifted Education Commons

\section{Recommended Citation}

Cross, Tracy L.; Cross, Jennifer Riedl; and O'Reilly, Colm, Attitudes about gifted education among Irish educators (2018). High Ability Studies, 29(2), 169-189.

https://doi.org/10.1080/13598139.2018.1518775

This Article is brought to you for free and open access by the School of Education at W\&M ScholarWorks. It has been accepted for inclusion in School of Education Articles by an authorized administrator of W\&M ScholarWorks. For more information, please contact scholarworks@wm.edu. 


\section{Attitudes About Gifted Education Among Irish Educators}

Tracy L. Cross, Ph.D.

Jennifer Riedl Cross, Ph.D.

William and Mary

Colm O'Reilly, Ph.D.

Dublin City University

Final version accepted for publication

Cross, T. L., Cross, J.R., \& O’Reilly, C. (2018). Attitudes about gifted education among Irish educators. High Ability Studies, 29(2), 169-189. 


\begin{abstract}
In 2018, gifted education has not been formalized in the Irish education system. To better advocate for the needs of high-ability students in Ireland, a survey was distributed to educators across the country $(N=837)$ regarding gifted education. A majority of respondents indicated their schools had systems in place to identify gifted students. Respondents were moderately supportive of special services for gifted students, but they were also moderately opposed to grade acceleration, a service option that has significant research support for its effectiveness. More school leaders than teachers believed teachers have the support they need to differentiate instruction, a potential challenge for the provision of services. A majority of classroom teachers did not perceive they had access to specialists to assist them in providing for their high ability students' needs. Comments from respondents indicate they would like to provide services, but lack the time, training, and resources to do so. Educators appear to be receptive to expanding gifted education in Ireland, but the survey results suggest a need for greater communication between school leaders and teachers, along with professional development on appropriate provisions.
\end{abstract}




\section{Attitudes About Gifted Education Among Irish Educators}

In Ireland, there has been sparse attention paid to the provision of special services for students with gifts and talents (O’Reilly, 2013). In schools that emphasize the maximal achievement for all students, special services may not be needed for students who are most capable. There is evidence, however, that this is not the case in many, perhaps most, Irish schools. The decline in scores from 2000 to 2009 on the Programme of International Student Assessment (PISA) among Irish students of all ability levels (Perkins, Moran, Cosgrove, \& Shiel, 2011) suggests that schools may need to give greater attention to maximizing the potential of all students, including those who can perform at the highest levels.

Among the nearly one million first- and second-level students in Irish schools (Ireland Department of Education and Skills, 2016), some proportion are capable of exceptional achievement. Assuming a normal distribution of ability, as we find with most measures of achievement or intelligence, there will be a top $10 \%, 5 \%$, and $1 \%$. In Ireland, this translates to nearly $92,000(10 \%), 46,000(5 \%)$, or 9,200 (1\%) students who might be considered gifted. One approach taken to serving these exceptional students in the US has been for many states to require that they be identified and served through the public schools (National Association for Gifted Children [NAGC] and the Council for State Directors of Programs for the Gifted, 2015). There is not a similar legal requirement in Ireland, although the 1998 Education Act specifies the Minister for Education and Science should "provide that, as far as is practicable and having regard to the resources available, there is made available to people resident in the State a level and quality of education appropriate to meeting the needs and abilities of those people" (italics added; Electronic Irish Statute Book, 2016). An appropriate education for the average student is 
not the same as an appropriate education for the most capable student (Coleman \& Cross, 2005). All students should have an education that is a good fit with their abilities.

One organization in Ireland has been catering for the needs of high-ability students since 1993. Developed from the model of the Center for Talented Youth at Johns Hopkins University in the US, the Irish Centre for Talented Youth (CTYI) on the campus of Dublin City University (DCU) has provided academic programs to nearly 50,000 primary and secondary students since its inception. CTYI programs are fee-based, but heavily subsidised for students who attend designated disadvantaged (Delivering Equality of Opportunity in Schools [DEIS]) schools. More than 1,500 students participate in CTYI programs in an average year. These students qualify by scoring in the $95^{\text {th }}$ percentile or higher on the SAT, a college-level achievement test. High-ability students often score at the highest level on grade-level achievement tests. A score of $100 \%$ may be meaningless, however, when a test is too basic for a student's true ability. Due to the limitations of this ceiling effect, out-of-level testing was created and offers an indication of what a student can actually do when untethered from assessments for her or his year in school (O’Reilly, Shelton, \& Apostolou, 2017; Stanley, 1976).

Students at CTYI take enrichment courses targeted at a high level, introducing them to advanced academic concepts and a wide variety of careers. When they come together on the DCU campus, students' excitement at being challenged and appreciated for what they can do is obvious to even the casual observer. Concern for these students' educational experience in their home schools led to the research questions guiding this study: 1) What are Irish educators' attitudes toward gifted education? and 2) Do teachers believe they have the support needed to serve gifted students in schools? A national study to explore these and other questions about gifted education was undertaken in 2014 by researchers at CTYI in collaboration with 
researchers at the College of William \& Mary Center for Gifted Education (Cross, Cross, O’Reilly, \& Mammadov, 2014). This manuscript describes the attitudes and perceptions of support among the groups of educators and administrators who make up the Irish schools.

\section{Attitudes Toward Gifted Education}

Research has identified mixed attitudes toward gifted education in the varied samples studied (e.g., Bégin \& Gagné, 1994a, 1994b; Colangelo \& Kelly, 1983; Cross, Cross, \& Frazier, 2013; Megay-Nespoli, 2001; Pierce \& Adams, 2000), with evidence for both strong support and strong opposition in North America. Most research exploring attitudes toward gifted education has been conducted with teacher or pre-service teacher samples. In their study of 139 professional educators and 138 parents of K-12 students in Canada, Bégin and Gagné (1994b) found that family income was directly related to support for gifted education: as income increased, so did support. Contact with gifted persons was also associated with more positive attitudes toward gifted education. Training in gifted education was associated with support for it in some studies cited in Bégin and Gagné's (1994a) review, but training did not make a difference in teachers' support in McCoach and Siegle's (2007) national sample of 262 US teachers. Cross, Cross and Frazier (2013) found that teachers who served gifted students in heterogeneous classes were less supportive of gifted education than were teachers in a specialized school for gifted high school students. In her study of nearly 400 elementary-level teachers, Chipego (2004) found that teachers' negative beliefs about parents of gifted students (e.g., as critical, overly demanding, adversarial, etc.) were predictive of their support - or lack thereof - for gifted education. Special education teachers were slightly less supportive of gifted education in McCoach and Siegle's study. 
Differentiated instruction has become the most common method for delivering services to gifted students in the US (NAGC, 2015). In this model, teachers are expected to tailor instruction to some degree, perhaps through flexible ability grouping or individualized instruction. When asked to rate the importance of providing various options of instruction to gifted students, more than $97 \%$ of the 411 administrators and teachers in Schroth's (2007) study considered differentiation of instruction in the regular classroom an important offering and most (71\%) considered it a "very important" option. No other method received such resounding support. Ireland's National Council for Curriculum and Assessment (NCCA), in its guidelines for teachers working with exceptionally able students, suggests, "[i]n most cases, the needs of exceptionally able students are best delivered as part of the normal differentiated classroom provision" (NCCA, 2007, p. 62). Although many agree that differentiation of instruction in the regular classroom is the best means of catering for gifted students, they often do not receive effective differentiation. In one observation study, $84 \%$ of activities in core classes of highability students were not differentiated (Westberg, Archambault, Dobyns, \& Salvin, 1993).

Teachers may resist differentiation for a variety of reasons, including worries about administrative support or having sufficient time for planning (Hertberg-Davis \& Brighton, 2006). Effective differentiation of instruction is a challenging task, requiring expertise and flexibility (VanTassel-Baska \& Stambaugh, 2005). About half of participants in Adams’s (2002) professional development workshops on differentiation were only interested in using differentiated materials that were supplied to them, not in actually creating differentiated lessons for their students. The preservice teachers in Moon, Callahan and Tomlinson's (1999) study believed that individual student needs should be accommodated, but there was a decline in these beliefs following their student teaching experience. Once they learned about the challenges 
facing them in a classroom, attending to different ability levels among students may have seemed a more daunting task. Mentorship of teachers learning to differentiate has been found an effective tool in maintaining a positive attitude towards this complex teaching strategy (Latz, Speirs Neumeister, Adam, \& Pierce, 2009; Moon, Callahan, \& Tomlinson, 1999).

Acceleration is a set of two dozen education approaches ranging from early entrance into kindergarten, to subject skipping, to grade skipping, to dual credit, and so forth. Its goal is to provide appropriate pacing or entrance based upon the individual student's readiness rather than her or his chronological age. Accelerative approaches receive frequent opposition from educators (Assouline, Colangelo, \& VanTassel-Baska, 2015). Southern, Jones and Fiscus (1989) surveyed 554 teachers and administrators regarding their beliefs about the positive and negative potentials of accelerating students. Even among the coordinators for gifted services in their sample, there was a consistent tendency to respond that accelerating students by grade-skipping is likely to cause students to miss important social interactions and create emotional difficulties. These beliefs are found relatively consistently in studies of attitudes toward acceleration (e.g., Rambo \& McCoach, 2012; Siegle, Wilson, \& Little, 2013), although not necessarily when surveying subjects who have experienced acceleration (Cross J. et al., 2013; Southern et al., 1989).

A substantial research base refutes the belief held by many that accelerating students will put them at a social disadvantage or create emotional problems (see Cross, Andersen \& Mammadov, 2015 for a review). Research indicates certain conditions make acceleration a less attractive option, such as when a sibling is in the target grade or when the student does not wish to make the move, but a student assessed to be a good candidate for acceleration who receives administrative and family support for the change is highly likely to be successful (LupkowskiShoplik, Assouline \& Colangelo, 2015). Acceleration has resulted in significant academic gains, 
even beyond the secondary level (Rogers, 2015) and social and emotional gains are often reported among students who found intellectual peers among older, more mature students (Gross, 2006).

With its historical emphasis on creating similar outcomes for all Irish students (O'Reilly, 2013), educators in Ireland are likely to have had little or no experience with providing special services to gifted students, including curriculum differentiation and acceleration. The Department of Education and Science (2007) has recommended differentiation for students with special educational needs (SEN), but the emphasis has been on serving the needs of students who cannot achieve without support, not those who are exceptionally able. Gifted students do not struggle with school in the same way as those on the opposite end of the ability spectrum, but require support to achieve their potential. A broad definition of exceptionally able students similar to that proposed in the Marland Report (1972) was included in a document of guidelines for Irish teachers (National Council for Curriculum and Assessment, 2007): “approximately 5$10 \%$ of the school population may be exceptionally able and will demonstrate very high levels of attainment in one or more of the following areas:

- general intellectual ability or talent

- specific academic aptitude or talent

- visual and performing arts and sports

- leadership ability

- creative and productive thinking

- mechanical ingenuity

- special abilities in empathy, understanding and negotiation.” (p. 8) 
This document indicates an emerging interest in providing services for these students. Effective advocacy for appropriate services for gifted students depends on an understanding of educators' attitudes and designing and delivering high quality professional development. In this study, we sought to clarify educators' attitudes about gifted education to paint a clear picture of the context in which high ability students are being educated in Irish schools. Advocacy efforts can be strengthened with a greater understanding of this context.

\section{Method}

\section{Participants}

Participants in the study were teachers $(n=470$; including special needs/resource teachers), school leaders and other staff ( $n=367$; including assistant principals and counselors) in schools from every county in the country of Ireland. Table 1 presents participant demographics. Participants represented a variety of school types and sizes (see Table 2). A majority of respondents were from public, primary schools and half were from small schools (fewer than 200 students). DEIS schools were well represented in the sample, with nearly 200 respondents indicating their school had this classification.

\section{Instruments}

Two versions of the survey were developed - one for teachers and one for school leaders and other staff. The instrument was made available online through Qualtrics, a survey software package, or in print form for paper-and-pencil completion. In addition to items about respondent and school demographics and school policies and practice, both versions included scales assessing opinions about the gifted and support for teachers. One open-ended item asked respondents to "Please share any additional comments about gifted education." 
Opinions About the Gifted. The 34-item Gagné and Nadeau (1985; Gagné, 1991) Opinions About the Gifted scale was modified to clarify the language and reduce the number of items. The resulting scale included in the survey consisted of 22 items representing five factors: Objections, Elitism, Support Due to Needs, Value, and Acceleration. Response options were from 1 = Strongly Disagree to $6=$ Strongly Agree .

Support for Teachers. Items in this section were adopted from Schroth (2007). These items explore perceptions of the support teachers have through access to specialists who can identify and work with gifted students and through support for differentiating curriculum for their gifted students. The stem of each item for teachers was, "As a teacher, I have...". For administrators, the stem was "The teachers at my school have...". Sample items are "access to specialist teachers to work with individual groups of gifted students in a special pull-out program" or "adequate planning time to differentiate instruction for varied abilities among students." Respondents were asked how much they agree on a 6-point scale from $1=$ Strongly Disagree, $2=$ Disagree, $3=$ Somewhat Disagree, $4=$ Somewhat Agree, $5=$ Agree, to $6=$ Strongly Agree.

\section{Procedure}

Teachers, school leaders, and other staff were invited to respond to the appropriate survey either by direct invitation from CTYI or through a mailing sent to all schools in Ireland. The mailing to 4,050 schools was submitted by CTYI to the Department of Education and Skills in Ireland and was delivered to schools in the first week of April, 2014. Instructions indicated how to distribute copies of the paper version included in the mailing and provided an alternative link to the appropriate versions of the online survey. Return envelopes were provided. A total of 456 
paper surveys were returned to CTYI for data entry. A further 381 surveys were submitted online.

\section{Results}

\section{Gifted Education in Irish Schools}

A majority of respondents $(64 \% ; n=537)$ reported that their school had a system for identification of gifted students. Eight percent $(n=63)$ did not know if their school had such a

system. In most cases, two or three criteria were reportedly used to identify students and this was most often in the form of psychometric tests and external judgments such as nominations, ratings, and interviews. A similar proportion of secondary $(66 \% ; n=397)$ and primary $(70 \% ; n=$ 134) school respondents reported identification policies in their schools. Respondents from large schools were significantly less likely to indicate they had a system for identifying gifted students than those in medium-sized to small schools, $\chi^{2}(4, N=776)=44.05, p<.001$.

Many respondents (37\%; see Table 3) reported that their schools had a policy regarding the acceleration of the regular curriculum for high ability students, but about half (47\%) reported that their school did not. Nine percent did not know if their school had an acceleration policy. Although only 307 respondents reported their school has an acceleration policy, 423 reported what type of policy was in place at their school. "Classroom teachers are encouraged to provide higher level or enriched content material in their classrooms, but are not permitted to accelerate students into the next level or academic grade" was the most frequently chosen option among those reporting a policy $(73.4 \% ; n=309)$. Nearly $20 \%(n=76)$ of respondents reported "Classroom teachers are encouraged to accelerate students into the next level or academic grade." Only four participants (1\%) indicated "Classroom teachers are not allowed to provide 
advanced level curriculum for higher ability students and are not permitted to accelerate students into the next level or academic grade."

Principals and assistant principals $(49 \% ; n=179)$ were more likely than teachers and special needs/resource teachers $(31 \% ; n=121)$ to respond "Yes" regarding an acceleration policy, $\chi^{2}(2, N=759)=72.74, p<.001$. Respondents from secondary schools were less likely to have an acceleration policy than did primary-school respondents, $\chi^{2}(4, N=771)=27.22, p$ $<.001$. Large-school respondents were significantly less likely to indicate that they had an acceleration policy than those in smaller schools, $\chi^{2}(4, N=773)=27.12, p<.001$. A higher percentage of large-school respondents than expected also did not know about their school's acceleration policy (21\%; see Table 3 ). This pattern of responses may indicate that information is less available to staff about identification of gifted students in larger schools or it may indicate larger schools are less likely than medium-sized or small schools to have such a system in place.

\section{Opinions about the Gifted}

The modified Opinions of the Gifted instrument required further adjustments. Reliability analysis led to elimination of the four Value items (e.g., "Gifted persons are a valuable resource for our society"), as several of these items had poor reliability. A fifth item was removed when it did not load on any factor in an exploratory factor analysis (principal axis factoring extraction and oblimin rotation). This editing resulted in three statistically sound factors that explained 53\% of the variance: Objections to special services $(\alpha=.86)$, opposition to Acceleration $(\alpha=.78)$, and Support due to needs of gifted students $(\alpha=.65)$. Elitism items were subsumed by the Objections factor.

High scores on the Objections and Acceleration factors and low scores on the Support factor indicate negative attitudes toward gifted education. Low scores on the Objections and 
Acceleration factors and high scores on the Support factor indicate support for gifted education. In general, the respondents who completed this portion of the survey $(n=706)$ were low in their objections to special services $(M=2.09, S D=.65)$, moderately opposed to grade acceleration $(M$ $=3.94, S D=.99)$, and moderately supportive of special services due to gifted students' needs $(M$ $=4.00, S D=.79)$. These opinions are consistent by school size, school level, position, and levels and subjects taught, with one exception. Primary school respondents $(M=4.01, S D=.97)$ were more opposed to acceleration than secondary school respondents $(M=3.71, S D=1.04), t(694)$ $=3.44, p<.05$. The six schools that included both levels were excluded from this analysis. There were not attitudinal differences among respondents in different positions (i.e., principals, classroom teachers).

Only 14 respondents $(2 \%)$ were actually opposed to gifted education, with an average score indicating agreement with the items on the Objections factor (e.g., agreeing with items such as "We should not have special education services for gifted children because our schools are already adequate in meeting the needs of the gifted."). A lack of support was more common, with 143 respondents $(17 \%)$ having average scores indicating disagreement with items on the Support factor (e.g., disagreeing with items such as "We should have special education services for gifted children because schools too often ignore the specific educational needs of the gifted."

\section{Teacher Support}

Respondents were asked how much they agreed (from $1=$ Strongly Disagree to $6=$ Strongly Agree) with statements that indicate support for teachers' time and materials to differentiate instruction for their students or their access to specialists. Univariate analysis of variance was conducted with each support factor to identify differences by school size, position, level or subjects taught, and DEIS school. Table 6 presents mean scores for each category. 
School size. Large-school participants were significantly less likely to perceive support to differentiate than those in small- or medium-sized schools, $F(2,705)=6.14, p<.01, \eta_{p}{ }^{2}=.02$. This perception does not differ within these school sizes by one's position at the school, $F(10$, $688)=1.46, p>.05$, or by the level or subject taught (differentiation support: $F(13,340)=1.04$, $p>.05$; access to specialists: $F(12,346)=1.5, p>.05)$. The high proportion of large schools that were secondary schools may explain these differences. There was not a significant difference by school size in perceptions of access to specialists, $F(2,709)=.841, p>.05$.

School level. Perceptions of support to differentiate were more positive among primary school respondents $(M=3.71, S D=1.08)$ than secondary $(M=3.30, S D=1.06), F(1,700)=$ $19.16, p<.01, \eta_{p}{ }^{2}=.03$. Access to specialists was also perceived more positively among respondents at primary $(M=3.02, S D=1.07)$ than secondary $(M=2.75, S D=1.01)$ schools, $F(1,704)=8.80, p<.01, \eta_{p}{ }^{2}=.01$. The very small effect size suggests negligible differences between primary and secondary school respondents. In general, respondents Somewhat Disagree that they have access to specialists for identification or services for gifted students. The six schools with both primary and secondary levels were not included in this analysis.

Position. Too few counselors and respondents in other positions completed this section of the survey to be included in the analysis. Classroom teachers, special needs/resource teachers, principals, and assistant principals perceived greater support to differentiate $(M=3.59, S D=$ 1.10) than access to specialists $(M=2.96, S D=1.06)$. This was confirmed by paired t-tests by position, with all $p s<.001$. Average scores for support to differentiate were between Somewhat Disagree and Somewhat Agree. Classroom and special needs/resource teachers' perceptions of the support they have for planning and providing differentiated instruction was significantly less than principals' and assistant principals perceptions $\left(F(3,691)=12.89, p<.001, \eta_{p}^{2}=.05\right)$. 
Despite this statistical significance, the very small effect size suggests that the practical significance of this difference in average scores is negligible.

Principals and special needs/resource teachers perceived teachers having greater access to specialists who can identify or work with gifted students than did classroom teachers $(F(3,695)$ $\left.=4.42, p<.01, \eta_{p}{ }^{2}=.02\right)$. Special needs/resource teachers had the most positive perception of their availability to classroom teachers. This may indicate a disconnect between the needs of teachers and the access to specialists that is actually available. Assistant principals reported a middle-of-the-road average, differing from neither of the other groups of respondents.

This analysis of average scores is clarified by an examination of the frequency of responses. Item responses were from $1=$ Strongly Disagree to $6=$ Strongly Agree . Individuals' responses were classified by their mean scores as high $(>4)$, moderate $(\geq 3$ and $<4)$, or low $(<$ 3). A higher percentage of classroom teachers (42\%) than principals $(28 \%)$ believed there is little support for them to differentiate instruction in the classroom, $\chi^{2}(10, N=692)=44.05, p<.001$. A higher proportion of principals (37\%) than classroom teachers $(20 \%)$ agreed that teachers have support to differentiate instruction (see Figure 1).

Perceptions of access to specialists were more nuanced than an aggregated analysis of teachers and principals suggests (see Figure 2). Special needs/resource teachers were more likely to think that teachers have access to specialists than did classroom teachers, $\chi^{2}(2, N=353)=$ 9.81, $p<.01$. Almost twice as many special needs/resource teachers (27\%) as classroom teachers (15\%) agreed that classroom teachers have access to specialists who can identify or work with their gifted students (high access category). Fifty-seven percent of classroom teachers disagreed that they have access to specialists (low access category), in contrast with $41 \%$ of special needs/resource teachers who shared this opinion. A smaller proportion of assistant principals 
(20\%) than principals (37\%) agreed that teachers had access to specialists (high access category), $\chi^{2}(2, N=342)=8.96, p<.05$. These frequency analyses provide a context for interpretation of the average score differences.

DEIS schools. Respondents from DEIS schools $(n=175)$ did not differ significantly from other respondents in their perceptions of support to differentiate instruction, $F(1,700)=$ $1.89, p>.05$. Perceptions of teachers' access to specialists was slightly higher among DEIS respondents $(M=3.12, S D=1.08)$ than others $(M=2.90, S D=1.05), F(1,704)=5.46, p<.05$, $\eta_{p}{ }^{2}=.01$. The very small effect size, however, suggests that this is not a practically significant difference. DEIS teachers and principals differed in their pattern of responses from the full sample, with all teachers and all principals perceiving similar levels of access to specialists.

Open-Ended Comments. Twenty-six percent $(n=219)$ of participants responded to the open-ended request for additional comments. A set of 20 codes were developed from a review of all comments. Individual comments were then assigned as many codes as applied. Many of the comments $(27 \%)$ concerned the lack of time and resources available to provide for gifted students. Large class sizes, "overloaded curricula," and insufficient funding make it difficult for teachers to meet all of their students' needs, leaving little time to address those of their gifted students. Twenty-one percent of the comments reflected the desire for gifted students to have more attention, particularly when significant time is spent on weaker students $(12 \%$ included reference to this dilemma). A recognition of gifted students' needs were evident in many comments (18\%). Sixteen percent of comments expressed strong sentiments against grade acceleration and separate classes for gifted students. A number of respondents commented on the need for teacher training (11\%). Exemplar comments are found in Table 7.

\section{Discussion}


Although the schools of a majority of the national sample surveyed in this study reportedly had a system for identifying gifted students, more than a third of respondents reported either no such system or did not know of one. Fewer than $40 \%$ of respondents reported having a school policy for accelerating the curriculum for high-ability learners. These statistics suggest that Irish schools have not yet fully invested in providing an appropriate education for their highability learners. There does appear to be broad support for providing special services for gifted students, but this does not include support for acceleration options, which have been found to be a very effective provision (Assouline, Colangelo, \& VanTassel-Baska, 2015). Despite the breadth of the support reported by respondents, the level of this support is relatively tepid.

Differentiating instruction for gifted students requires a commitment of time and resources. Educators from large schools, in particular, did not perceive they have the support they needed to differentiate instruction for their gifted students. Ideally, all educators would strongly agree that they have such support, but scores suggest ambivalence about the support teachers receive. Principals and teachers had differing perspectives on the support teachers have to provide these services. It may be that principals have not effectively communicated their support for teachers to spend the time or acquire the materials necessary for true differentiation. Another possibility is that principals are unaware of the demands that differentiation places on teachers and mistakenly believe their teachers have what is needed to be successful. In either situation, a closer look at the support teachers actually have for effectively differentiating instruction is warranted.

Specialists can support teachers in this effort, by offering instruction to gifted students in the classroom or through a pull-out program. Although a higher percentage of special needs/resource teachers than classroom teachers report that teachers have access to specialists to 
help with their high-ability students, a majority of all teachers do not consider this to be the case. Educators who work in DEIS schools are more aligned in their perceptions of teachers' access to specialists. Specialists may be more widely available than classroom teachers are aware in nonDEIS schools, in which case professionals across the country may benefit from more information-sharing regarding specialist services.

Building awareness of gifted education and the needs of gifted students is a first step in making it a reality. Educators across the country made a commitment of their time to complete this survey, which included several components not described here (see Cross, et al., 2014, for the full report). There are large-scale historical changes as well as specific performance-based factors (e.g., decline in PISA scores) at play at this time in history in the evolution of the Irish schools. For example, Irish schools are changing to increasingly include options that are less formally connected to the Catholic Church, which dominated the Irish education system throughout the $20^{\text {th }}$ century (O'Reilly, 2013). In addition, as the students making up the Irish schools become more ethnically and culturally diverse, best practices in education are being incorporated that include greater attention to the needs of the individual student. Strategies touted by gifted educators, such as curriculum differentiation, have been embraced as best practice in general education, so pedagogical lines that have separated regular, gifted education, and special education are becoming blurred. This means that the evolution of Irish schools, in order to be equally effective at both the aggregate level (indicators that can be measured by national standardized tests) and the individual level (specific types of instructional practice tailored for the needs of the individual student), is being partially realized. Although the survey comments paint a picture of considerable unevenness across the country relative to the implementation of gifted education strategies and techniques, growing attention to the plight of underserved high- 
ability students in Ireland will hopefully result in improved chances that all Irish students will have an equal opportunity to receive an appropriate, challenging education. The national priority for differentiation (DES, 2007) can help make this a reality, if it brings about professional development and mentorship for teachers and the small class sizes necessary for them to be effective.

\section{Conclusion}

The results of this study, that educators believe that most schools have policies for gifted education, that most educators believe that gifted students need additional attention for them to flourish in school, that, in many cases, educators in supportive roles are in place and are available to help the classroom teachers differentiate instruction, bodes well for the future. Support for gifted education may be greater when principals and teachers are in agreement about the requirements of differentiation. Greater accord between principals' and teachers' perceptions will be necessary to overcome the practical limitations preventing differentiation from becoming mainstream. To reach the point where all Irish students have the same possibility of receiving the most appropriate education will require better resources, more effective communication across groups of stakeholders (e.g., administrators, teachers, special educators, support teachers, counselors parents), and additional training and time to appropriately develop the curriculum materials.

As is common in other Western countries, Irish educators expressed the desire to employ certain strategies over others. For example, Irish educators expressed a preference to keep students of the same age together in the same classroom and with the same teacher. They may prefer this because they feel confident in their own ability to differentiate appropriately and because they worry that the students will experience negative social consequences if they are 
allowed to be accelerated or pulled out of the classroom, or to attend special classes, a common concern about acceleration (Assouline et al., 2015). With such concerns, educators may perceive that special treatment generally, and acceleration, specifically, will cause the students social and emotional problems. As a consequence, some educators are reluctant to utilize gifted education strategies other than differentiation in a heterogeneous classroom. With professional development that is grounded in the research base on best practice in gifted education, Irish educators may become more accepting of acceleration.

This study described a fertile ground for moving in the direction of curriculum differentiation as a tool to improve the education of all students, including students with gifts and talents. While the educators support the need and acknowledge in many cases that a gifted education policy exists locally, in many cases the educators commented that they feel illequipped or too overwhelmed by the work conditions of their schools to engage in differentiation. Without broader policy regarding gifted learners, teachers are unlikely to receive professional development to develop their classroom practice, administrative focus will be on the substantially greater number of average students or the mandated SEN. In such an environment, the students who are capable of achieving at exceptional levels will not reach their potential, a loss to the individual and society. The educational stage is set for this evolutionary step that can help Irish schools meet the goals they have for their students.

\section{Limitations}

The invitation to participate in this study was distributed widely across the country. However, the sample of educators who responded may represent the ends of a continuum in their attitudes toward gifted education. These are not the only responses, as the examination of frequencies of high and low attitudes indicates. The instrument was purposefully developed from 
a variety of sources, but surveys are subject to inherent weaknesses (Groves, 1989). The

Opinions of the Gifted (Gagné \& Nadeau, 1985) scale was modified to improve validity and adapted for this study, with acceptable statistical reliability. The length of the survey precluded the inclusion of a test for socially desirable responding. This may not be of concern, however, as it is unclear what educators may consider socially desirable in regard to education of gifted students.

\section{References}

Adams, C. (2002). Professional development: 5, 9-10.

Assouline, S. G., Colangelo, N., \& VanTassel-Baska, J., (2015). A nation empowered: Evidence trumps the excuses holding back America's brightest students (Vol. 1). Iowa City, IA: Belin Blank Center for Talent Development.

Bégin, J., \& Gagne, F. (1994a). Predictors of attitudes toward gifted education: A review of the literature and a blueprint for future research. Journal for the Education of the Gifted, $77(2), 161-179$.

Bégin, J., \& Gagne, F. (1994b). Predictors of a general attitude toward education. Journal for the Education of the Gifted, 18(1), 74-86.

Chipego, A. D. (2004). Factors associated with the attitudes of elementary level classroom teachers toward gifted education. Dissertation Abstracts International.

(UMINo.3120729)

Colangelo, N., \& Kelly, K. (1983). A study of student, parent, and teacher attitudes toward gifted programs and gifted students. Gifted Child Quarterly, 27(3), 107-110. 
Coleman, L. J., \& Cross, T.L. (2005). Being gifted in school: An introduction to development, guidance and teaching (2nd ed.). Waco, TX: Prufrock Press.

Cross, J. R., Cross, T. L., \& Frazier, A. D. (2013). Student and teacher attitudes toward giftedness in a two laboratory school environment: A case for conducting a needs assessment. NALS Journal, 5(1). Retrieved from http://digitalcommons.ric.edu/nals/vol5/iss1/1

Cross, J. R., Cross, T. L., O’Reilly, C., \& Mammadov, S. (2014). Gifted education in Ireland: Educators' beliefs and practices. Report prepared for Centre for Talented Youth Ireland.

Department of Education and Science. (2007). Inclusion of students with special educational needs: Post-Primary guidelines. Dublin, IR: Author.

Electronic Irish Statute Book. (2016). Education Act, 1998. Retrieved from http://www.irishstatutebook.ie/eli/1998/act/51/enacted/en/print\#sec6

Gagné, F. (1991). Brief presentation of Gagné and Nadeau's attitude scale "Opinions about the gifted and their education." Unpublished manuscript.

Gagné, F., \& Nadeau, L. (1985). Dimensions of attitudes towards giftedness. In A. H. Roldan (Ed.), Gifted and talented children, youth, and adults: Their social perspective and culture (pp. 148-170). Monroe, NJ: Trillium.

Gross, M. U. M. (2006). Exceptionally gifted children: Long-term outcomes of academic acceleration and nonacceleration. Journal for the Education of the Gifted, 29, 404-429.

Groves, (1989). Survey errors and survey costs. Hoboken, NJ: John Wiley \& Sons.

Hertberg-Davis, H. L., \& Brighton, C. M. (2006). Support and sabotage: Principal's influence on middle school teachers' responses to differentiation. Journal of Secondary Gifted Education, 17, 90-102. 
Ireland Department of Education and Skills. (2016). Key Statistics 2014/2015: Number of fulltime students in institutions aided by the Department of Education and Skills 2013/2014 and 2014/2015. Retrieved from http://www.education.ie/en/Publications/Statistics/Key-Statistics/Key-Statistics-20142015.pdf

Latz, A. O., Speirs, Neumeister, K. L., Adams, C. M., \& Pierce, R. L. (2009). Peer coaching to improve classroom differentiation: Perspectives from Project CLUE. Roeper Review, 31, 27-39.

Lupkowski-Shoplik, A., Assouline, S. G., \& Colangelo, N. (2015). Whole-grade acceleration: Grade-skipping and early entrance to kindergarten or first grade. In S. G. Assouline, N. Colangelo, J. VanTassel-Baska, \& A. Lupkowski-Shoplik (Eds.), A nation empowered: Evidence trumps the excuses holding back America's brightest students (Vol. 2; pp. 5371). Cedar Rapids, IA: Belin-Blank Center.

Marland, S. P., Jr. (1972). Education of the gifted and talented: Report to the Congress of the United States by the U.S. Commissioner of Education and background papers submitted to the U.S. Office of Education, 2 vols. Washington, DC: U.S. Government Printing Office. (Government Documents, Y4.L 11/2: G36)

McCoach, D. B., \& Siegle, D. (2007). What predicts teachers' attitudes towards the gifted? Gifted Child Quarterly, 51(3), 246-255.

Megay-Nespoli, K. (2001). Beliefs and attitudes of novice teachers regarding instruction of academically talented learners. Roeper Review, 23, 178-182. 
National Association for Gifted Children and the Council for State Directors of Programs for the Gifted. (2015). 2014-2015 State of the states in gifted education. Washington, DC: NAGC.

National Council for Curriculum and Assessment. (2007). Exceptionally able students: Draft guidelines for teachers. Dublin, IR: Department of Education and Skills.

O'Reilly, C. (2013). Gifted education in Ireland. Journal for the Education of the Gifted, 36, 9718. doi:10.1177/0162353212470039

O’Reilly, C., Shelton, A. L., \& Apostolou, A. (2017). Out-of-school programmes for gifted students using a Talent Search identification model. In J. R. Cross, C. O’Reilly, \& T. L. Cross (Eds.), Providing for the special needs of students with gifts and talents (pp. 125152). Dublin, Ireland: CTYI Press.

Perkins, R., Moran, G., Cosgrove, J., \& Shiel, G. (2011). PISA 2009: The performance and progress of 15-year-olds in Ireland. Dublin, IR: Educational Research Centre.

Pierce, R. L., \& Adams, C. M. (2000). Attitudes of preservice and experienced teachers toward gifted learners: An expanded abstract. Retrieved from www.hiceducation.org/Edu_Proceedings/Rebecca\%20L.\%20Pierce.pdf.

Rambo, K. E., \& McCoach, D. B. (2012). Teacher attitudes toward subject-specific acceleration: Instrument development and validation. Journal for the Education of the Gifted, 35, $129-152$.

Rogers, K. (2015). The academic, socialization, and psychological effects of acceleration: Research synthesis. In S. G. Assouline, N. Colangelo, \& J. VanTassel-Baska (Eds.), A nation empowered: Evidence trumps the excuses holding back America's brightest students (Vol. 2; pp. 19-29). Iowa City, IA: Belin Blank Center for Talent Development. 
Schroth, S. T. (2007). Perceptions of gifted programming: Degree of alignment in administrator, teacher, and gifted specialist beliefs (Unpublished doctoral dissertation). University of Virginia, Charlottesville, VA.

Siegle, D., Wilson, H. E., \& Little, C. A. (2013). A sample of gifted and talented educators' attitudes about academic acceleration. Journal of Advanced Academics, 24, 27-51.

Southern, W. T., Jones, E. D., \& Fiscus, E. D. (1989). Practitioner objections to the academic acceleration of gifted children. Gifted Child Quarterly, 33, 29-35.

Stanley, J.C. (1976). Identifying and nurturing the intellectually gifted. Phi Delta Kappa, 58, 234-237.

VanTassel-Baska, J., \& Stambaugh, T. (2005). Challenges and possibilities for serving gifted learners in the regular classroom. Theory into Practice, 44, 211-217.

Westberg, K. L., Archambault, F. X., Dobyns, S. M., \& Salvin, T. J. (1993). The classroom practices observation study. Journal for the Education of the Gifted, 16, 120-146. 
Table 1

Respondent Demographics

\begin{tabular}{|c|c|c|c|c|c|c|c|c|c|c|c|c|c|}
\hline & \multicolumn{2}{|c|}{ Gender } & \multicolumn{6}{|c|}{ Years of teaching experience } & \multicolumn{4}{|c|}{ Highest degree } & \multirow[b]{2}{*}{$\begin{array}{c}\text { Professional } \\
\text { Diploma }\end{array}$} \\
\hline & Male & Female & $0-5$ & $6-10$ & $11-15$ & $16-20$ & $21-30$ & $31+$ & Bachelor's & Master's & Ed.S. & Ph.D. & \\
\hline $\begin{array}{l}\text { Classroom } \\
\text { Teacher }\end{array}$ & 61 & 238 & 93 & 84 & 61 & 24 & 27 & 12 & & 23 & 20 & 26 & 85 \\
\hline $\begin{array}{c}\text { Special } \\
\text { Needs/Resource } \\
\text { Teacher }\end{array}$ & 6 & 124 & 18 & 24 & 26 & 24 & & & 40 & 13 & 21 & 4 & 46 \\
\hline Principal & 72 & 210 & 1 & 12 & 37 & 27 & & 103 & 90 & 46 & 15 & 19 & 99 \\
\hline $\begin{array}{l}\text { Assistant } \\
\text { Principal }\end{array}$ & 11 & 77 & 2 & 10 & 13 & & 28 & 25 & 29 & 10 & 8 & 5 & 32 \\
\hline Counselor & 2 & 7 & & & & & & & 0 & 4 & 1 & 0 & 4 \\
\hline Other & 5 & 10 & & & & & & & 3 & 1 & 0 & 1 & 5 \\
\hline Total & 157 & 666 & 114 & 130 & 137 & 84 & 188 & 151 & 290 & 97 & 65 & 55 & 271 \\
\hline
\end{tabular}


Table 2

Respondent School Information

\begin{tabular}{|c|c|c|c|c|c|c|c|c|c|}
\hline & \multicolumn{3}{|c|}{ School Level } & \multicolumn{2}{|c|}{ School Type } & \multicolumn{3}{|c|}{ School Size } & \multirow[b]{2}{*}{$\begin{array}{c}\text { DEIS } \\
\text { school }\end{array}$} \\
\hline & Primary & Secondary & $\begin{array}{l}\text { Both primary } \\
\text { and secondary }\end{array}$ & Public & Private & $\begin{array}{l}\text { Small } \\
\leq 200\end{array}$ & $\begin{array}{c}\text { Medium } \\
>200 \leq 500 \\
\end{array}$ & $\begin{array}{c}\text { Large } \\
>500 \\
\end{array}$ & \\
\hline $\begin{array}{l}\text { Classroom } \\
\text { Teacher }\end{array}$ & 168 & 103 & 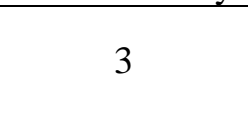 & 257 & 18 & 94 & 108 & 71 & 80 \\
\hline $\begin{array}{c}\text { Special } \\
\text { Needs/Resource } \\
\text { Teacher }\end{array}$ & 101 & 19 & 4 & 116 & 9 & & 56 & 17 & 26 \\
\hline Principal & 236 & 46 & 0 & 274 & & 211 & 70 & 2 & 67 \\
\hline $\begin{array}{l}\text { Assistant } \\
\text { Principal }\end{array}$ & 62 & 24 & 0 & 81 & 5 & 47 & 24 & 15 & 17 \\
\hline Counselor & 0 & 8 & 0 & & 0 & 5 & 1 & 2 & 6 \\
\hline Other & 1 & 7 & 0 & 7 & 2 & 5 & 3 & 1 & 1 \\
\hline Total & 568 & 207 & 7 & 743 & 41 & 413 & 262 & 108 & 197 \\
\hline
\end{tabular}

Table 3

System to Identify and Acceleration Policy

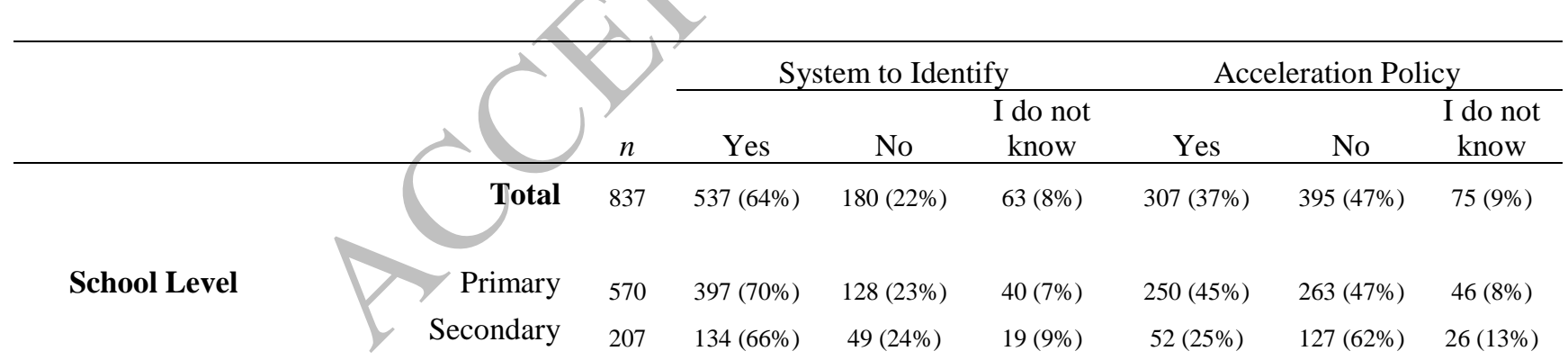




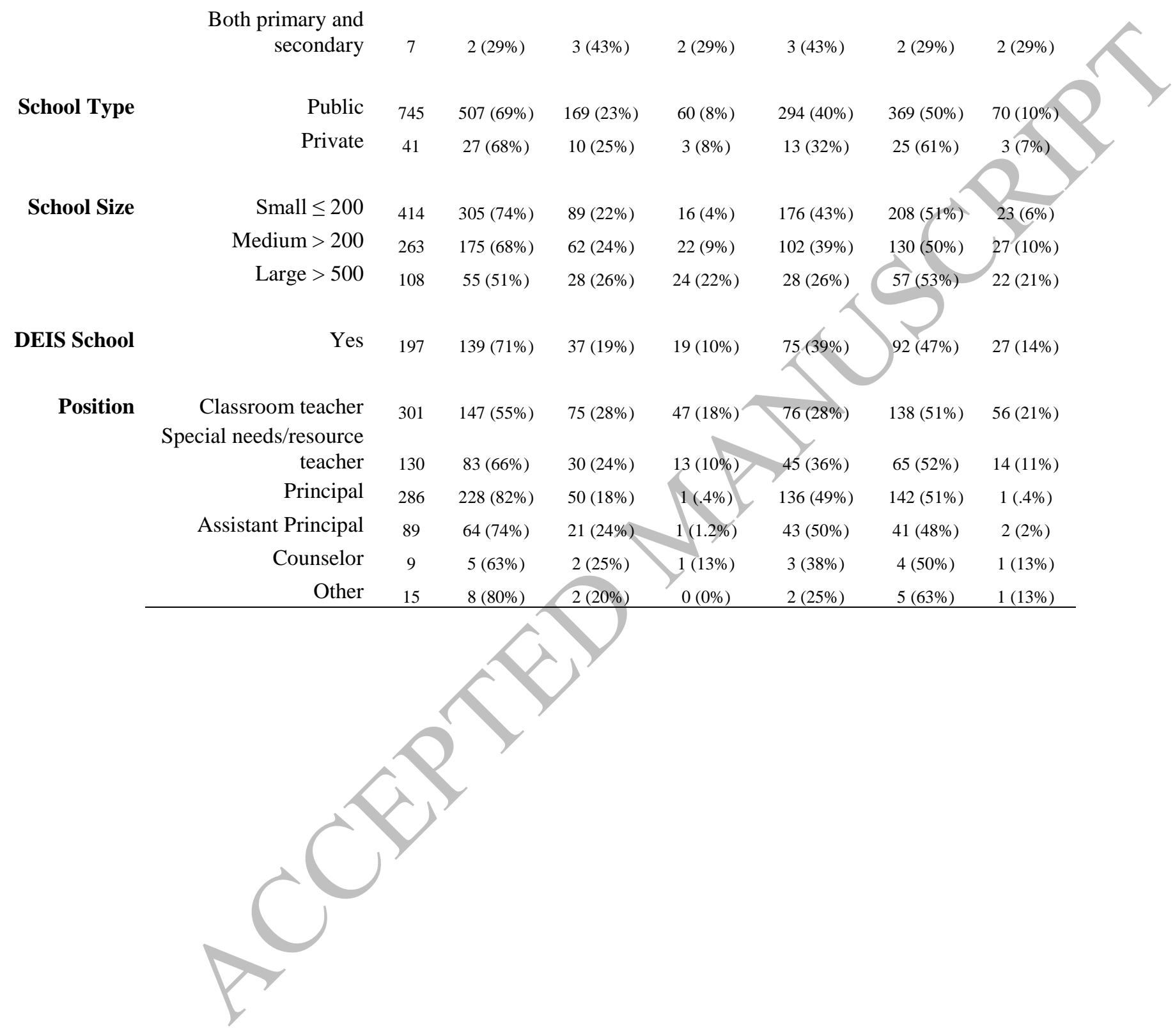


Table 4

Pattern Matrix Factor Loadings

\begin{tabular}{|c|c|c|c|}
\hline & \multicolumn{3}{|c|}{ Factor } \\
\hline & Objections & Acceleration & Support \\
\hline $\begin{array}{l}\text { We should not have special programs for gifted } \\
\text { children because it is an unfair advantage for them } \\
\text { to receive special educational services. }\end{array}$ & 0.736 & 0.05 & 0.056 \\
\hline $\begin{array}{l}\text { We should not have special programs for gifted } \\
\text { children because they are already favored in our } \\
\text { schools. }\end{array}$ & 0.695 & & -0.03 \\
\hline $\begin{array}{l}\text { We should not have special programs for gifted } \\
\text { children, because they are elitist. }\end{array}$ & & 0.027 & 0.096 \\
\hline $\begin{array}{l}\text { We should not have special education services for } \\
\text { gifted children, because we have a greater moral } \\
\text { responsibility to give special help to children with } \\
\text { difficulties than gifted children. }\end{array}$ & & -0.002 & 0.036 \\
\hline $\begin{array}{l}\text { We should not have special programs for gifted } \\
\text { children, because, when gifted children are put in } \\
\text { special classes, it makes other children feel they are } \\
\text { less valued. }\end{array}$ & 0.652 & 0.12 & 0.122 \\
\hline $\begin{array}{l}\text { We should not have special education services for } \\
\text { gifted children, because children with difficulties } \\
\text { need special education services the most. }\end{array}$ & 0.651 & 0.025 & 0.036 \\
\hline $\begin{array}{l}\text { We should get rid of all special programs for the } \\
\text { gifted. }\end{array}$ & 0.575 & -0.008 & -0.105 \\
\hline $\begin{array}{l}\text { Taxpayers should not have to pay for special } \\
\text { education for the children who are gifted. }\end{array}$ & 0.548 & -0.009 & -0.008 \\
\hline $\begin{array}{l}\text { We should not have special education services for } \\
\text { gifted children because our schools are already } \\
\text { adequate in meeting the needs of the gifted. }\end{array}$ & 0.538 & -0.03 & -0.281 \\
\hline $\begin{array}{l}\text { (-)Our schools should offer special education } \\
\text { services for the gifted. }\end{array}$ & 0.43 & -0.044 & -0.194 \\
\hline $\begin{array}{l}\text { Gifted children should not be allowed to skip a } \\
\text { grade because they will miss important ideas. }\end{array}$ & 0.098 & 0.783 & 0.018 \\
\hline $\begin{array}{l}\text { (-) A greater number of gifted children should be } \\
\text { allowed to skip a grade. }\end{array}$ & -0.106 & 0.713 & -0.249 \\
\hline $\begin{array}{l}\text { Gifted children should not be allowed to skip a } \\
\text { grade because, they will have trouble adjusting } \\
\text { socially to being with other students. }\end{array}$ & 0.116 & 0.699 & 0.079 \\
\hline
\end{tabular}


We should have special education services for gifted children because the regular school program stifles gifted children's intellectual curiosity.

We should have special education services for gifted children because gifted children waste their time in regular classes.
0.125
$-0.084$
0.531

We should have special education services for gifted children because schools too often ignore the specific educational needs of the gifted.

We should have special education services for gifted children, because gifted children are often bored in school. 
Table 5

Items Assessing Support for Services

\section{Support to differentiate instruction}

“As a teacher, I have..." or "At my school, teachers have..."

... adequate planning time to differentiate instruction for varied abilities among students.

... access to the instructional materials necessary to differentiate instruction.

... adequate planning time to accelerate instruction.

... access to the instructional materials necessary to accelerate instruction.

... support of school administrators for the appropriate planning and implementation of differentiated instruction.

... support of fellow teachers for the appropriate planning and implementation of differentiated instruction.

\section{Access to specialists}

"As a teacher, I have..." or "At my school, teachers have..."

... access to specialist teachers to work with individual groups of gifted students in a special pull-out program.

... sufficient space for specialist teachers to work with individual groups of students, including gifted students, in their regular classrooms.

... access to specialists within my school who can identify gifted students.

... access to specialists outside of my school who can identify gifted students.

Note: Adapted from Schroth, 2007 
Table 6

ANOVA Results: Teacher Support

\begin{tabular}{|c|c|c|c|c|}
\hline & \multicolumn{2}{|c|}{ Support for Differentiation } & \multicolumn{2}{|c|}{ Access to Specialists } \\
\hline & $n$ & Mean (SD) & $n$ & Mean (SD) \\
\hline \multicolumn{5}{|l|}{ School Size } \\
\hline Small $\leq 200$ & 379 & $3.67(1.08)^{\mathrm{a}}$ & 382 & $2.99(1.05)$ \\
\hline Medium $\leq 500$ & 233 & $3.62(1.10)^{\mathrm{b}}$ & 236 & $2.95(1.09)$ \\
\hline Large $>500$ & 96 & $3.24(1.04)^{\mathrm{a}, \mathrm{b}}$ & 94 & $2.83(1.06)$ \\
\hline \multicolumn{5}{|l|}{ School Level } \\
\hline Primary & 521 & $3.71(1.08)$ & 530 & $3.02(1.07)$ \\
\hline Secondary & 181 & $3.30(1.06)$ & 176 & $2.75(1.01)$ \\
\hline $\begin{array}{r}\text { Both Primary } \\
\text { and Secondary }\end{array}$ & 6 & $2.92(1.08)$ & 6 & $2.88(1.06)$ \\
\hline DEIS School & 172 & $3.70(1.14)$ & & $(1.08)$ \\
\hline \multicolumn{5}{|l|}{ Position } \\
\hline $\begin{array}{r}\text { Classroom } \\
\text { Teacher }\end{array}$ & 238 & $3.32(1.09)^{\mathrm{c}}$ & & $2.78(1.03)^{\mathrm{c}, \mathrm{d}}$ \\
\hline Special Needs/ & & & & \\
\hline $\begin{array}{r}\text { Resource } \\
\text { Teacher }\end{array}$ & 109 & $3.47(.97)^{\mathrm{d}}$ & 112 & $3.12(.98)^{\mathrm{c}}$ \\
\hline Principal & 265 & $3.9(1.08)^{\mathrm{c}, \mathrm{d}}$ & 264 & $3.07(1.07)^{\mathrm{d}}$ \\
\hline $\begin{array}{l}\text { Assistant } \\
\text { Principal }\end{array}$ & 83 & $3.65(1.00)$ & 82 & $2.88(1.56)$ \\
\hline Total & 695 & $3.60(1.09)$ & 699 & $2.96(1.05)$ \\
\hline
\end{tabular}

Note. Same superscript letters indicate means differing significantly at $p$ $<.05$ with Tukey's post-hoc analysis. 
Table 7

Exemplar responses to prompt "Please share any additional comments about gifted education."

Category Comment

Insufficient

time/resources

With differentiated curricula we should be better able to cater for the gifted student. However, it has to be said that the children with special needs often take priority over the gifted child.... who it has to said also has a special need. I totally agree that it can be very boring for students who are gifted to have to listen to the re-iteration of information when they have already grasped the concept. More resources are needed to cope and the gifted students should be catered for equally.

Class size is a huge consideration. Teachers would love to give more time to planning rewarding educational experiences for all the children in their classes but huge numbers make this difficult.

Desire for

more

services

I do not think that special programmes for gifted children and special programmes for children with learning difficulties should be mutually exclusive. Under the education Act (1998) all children in this state are entitled to an education appropriate to their needs. I believe both groups should have the right to attend mainstream schools, if it is in the child's best interest, but should get specialist supports.

The same resources that are put into special education should be afforded to gifted children. Every child, no matter which extreme of abilities, must be helped to reach his/her potential. Our system cannot be hit or miss. We teach to the average ability child.

Time spent

on weaker

students

It is not an area that we would devote much time to thinking about as we are stretched as it is trying to cater for the children with special needs in our busy classrooms with high pupil class numbers. As a teacher, priority has to be given to the pupils who are struggling with the basics in literacy and numeracy before we can cater for gifted children. Where possible 
teachers who allow gifted pupils to move beyond the core classwork and engage in supplementary class material, computers, etc.

Currently our class numbers have increased and in class supports have dropped. I spend most of my time trying to support my weakest children. It sounds bad but I do not have the time to spend with my more able children, Although I give them more challenging work to complete when they are finished class work, I do not have the time to do anything else.

Gifted students have needs
A child may be gifted in one area but have educational needs in another area. We need to focus on teaching individuals' needs rather than class teaching.

I feel that there should be more training courses for teachers to both A: Recognise a gifted child

B: Plan, differentiate + teach a gifted child

Also to understand that gifted children may speak their mind + may not be being precocious or cheeky
Do not separate or skip grades
Gifted children should be in school with children their own age. However, their abilities should be recognised and supported.

Academically gifted children need to be challenged academically but also allowed to be children and allowed to mature socially and emotionally at an appropriate speed for their age. They can often been vulnerable if they are pushed to be more grown up due to their academic abilities. They also need to mix with their peers to learn how to be with the rest of the world so that they don't struggle with intolerance as adults

\section{Need for training}

There needs to be more information and training available for teachers. Firstly teachers need to know how to identify gifted children and then to learn how to accommodate them in the classroom and help them to realise their potential.

Teachers need more support in identifying them and teaching them adequately. 
Provision should be made explicitly for SEN teachers to support these children and allocations of such teachers should be increased accordingly. 
Figure 1. Percentages of teachers and principals with perceptions of low, moderate, or high teacher support to differentiate.

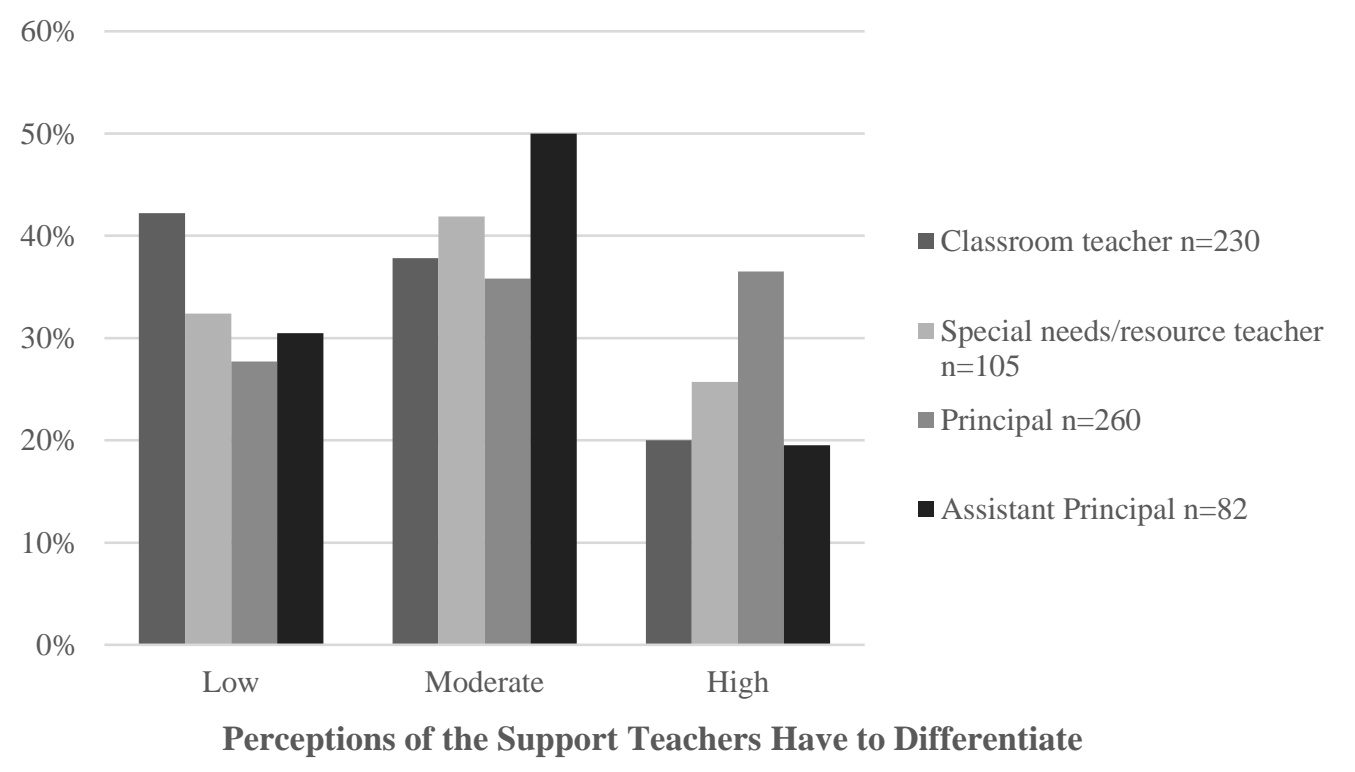


Figure 2. Percentages of teachers and principals with perceptions of low, moderate, or high teacher access to specialists.
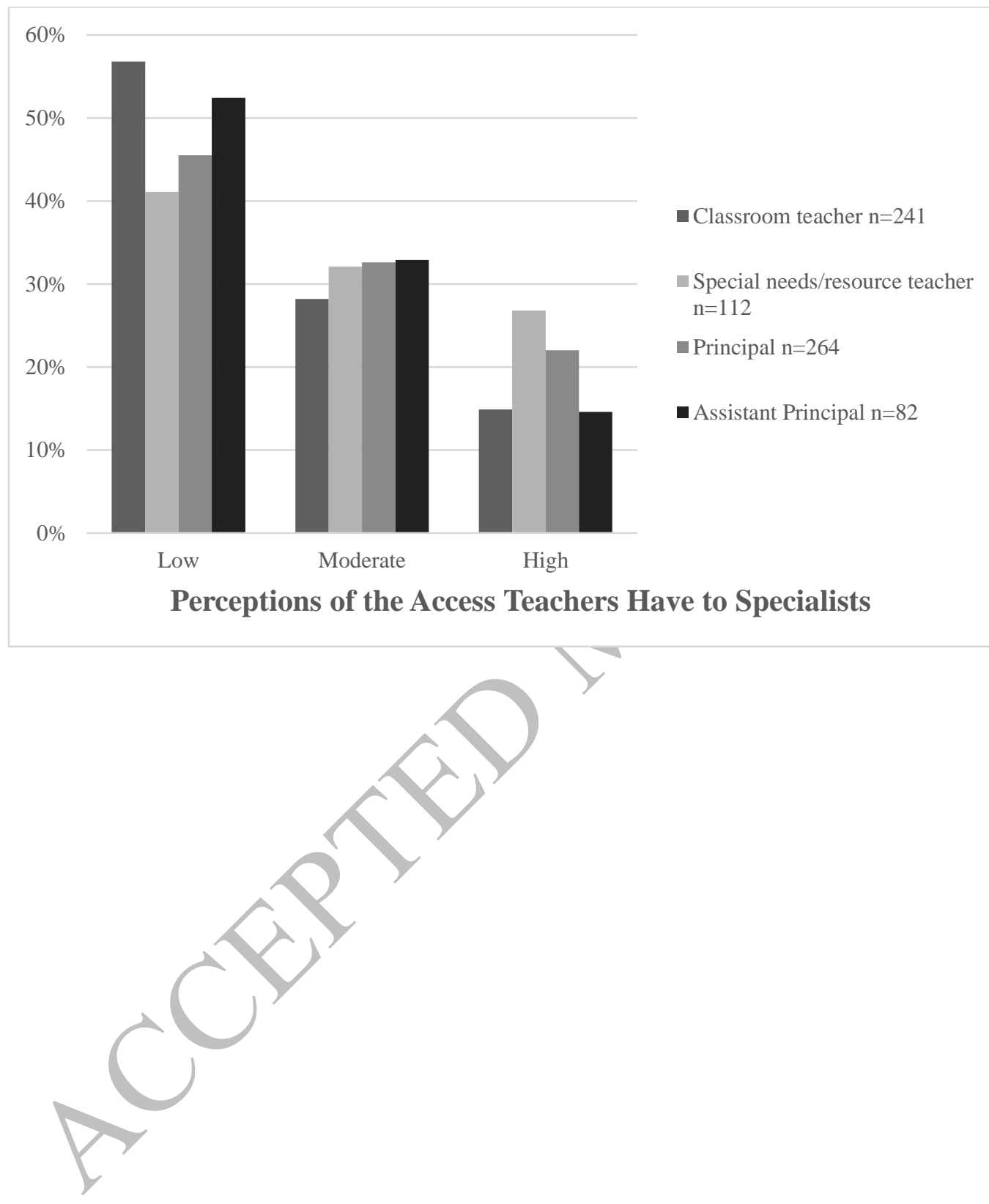